\title{
Management Of Academic Quality: A Comparison Of Online Versus Lecture Course Outcomes
}

\author{
Marian C. Schultz, University of West Florida, USA \\ James T. Schultz, Embry-Riddle Aeronautical University, USA \\ Gene Round, Embry-Riddle Aeronautical University, USA
}

\begin{abstract}
This study compared the final grades of courses taught both through distance learning (online) and the traditional classroom (lecture) delivery mode. This research sought to determine if a significant difference existed between the grades of the two identified delivery modes. Four courses taught by Embry Riddle Aeronautical University were selected for the study. Grades for the 2005 and 2006 calendar years were compared to determine if significance exists between the two modes. The study found that in the case of all four classes a significant difference was found in the final grades. In each case, the mean grade for the online courses was significantly less than those of the traditional lecture classes.
\end{abstract}

Keywords: online, distance learning

\section{INTRODUCTION}

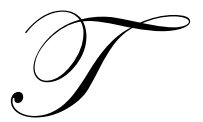

he emergence of online educational programs has initiated a discussion pertaining to the academic quality of the courses. Especially with the onset of online testing, there has been a valid concern pertaining to the grades which students receive in online courses, questioning whether they are statistically different from students taking traditional (lectures) classroom courses. This study compared the final course grades associated with distance learning and traditional classroom courses. The study examined whether significant grade differences existed between the two delivery modes. The four Embry Riddle Aeronautical University courses were selected and their grades for the 2005 and 2006 calendar years were compared to determine if significance between the two delivery modes existed.

\section{THE HISTORY OF DISTANCE EDUCATION}

Distance education has progressed through correspondence, sound and video signals (telephones, radio and television) and computer technology supported learning (Tatkovic \& Ruzic, 2006). The technology-based distance education initially integrated instructional slides and motion pictures as far back as 1910 (Jeffries, n.d.). Education outside the primary campus continued to offer learning opportunities since 1980. Early correspondence courses, as the first recorded form of distance learning, exemplified participant interaction through the distribution of printed material through the mail. Correspondence study has been a noteworthy component of the University of Wisconsin delivery system since 1891. Correspondence courses supplied comprehensive training and grew in popularity rapidly, "...culminating with legislation in 1911 that provided for local 'continuation schools' in cities of more than 5,000" (Gooch, 1998). In 1911, the report from the University of Wisconsin's Engineering Extension Department acknowledged that engineering students who completed correspondence courses were among the best members of university classes (Gooch, 1998).

The second phase of distance education was set in motion in the early 1960s with experimental radio (WHA Radio) broadcast of educational courses in a variety of formats. WHA Radio initially known as "College of 
the Air" and later "University of the Air" arranged for professors from the University of Wisconsin to remotely discuss a wide selection of educational topics. During the 1960s, the University of Wisconsin at Madison was renowned as a distance education institution. The University of Wisconsin and University Extension specialists contributed to the development of distance teaching systems required to establish the British Open University. In 1971, the WHA Radio worked with University of Wisconsin to generate national audio credit courses. During the 1980s, 200 faculties were participating in informational and WHA short course programs. Subsequently, in 1992 WHA radio broadcasted news and information to 16 county areas of south Wisconsin (Gooch, 1998).

Television, as another instructional medium, became the ensuing step in the distance education process. By the 1960s, 53 television stations were allied with the National Educational Television Network (NET) thereby allowing the exchange and sharing of instructional materials (Jeffries, n.d.). The 233 educational stations in existence by the 1970s included Ohio University, University of Texas and the University of Maryland. These universities represented the earliest institutions to create networks reaching students regardless of their primary affiliation on or off campus. WHA-TV station had also become a "...major producer of local statewide and national general educational programming, focusing on cultural performing arts, sports, and public affairs themes" (Gooch, 1998, p. 3). The TV station offered both credit and non-credit courses developed by UW System campuses.

Similarly, the 1960s revealed the Midwest Program on Airborne Television Instruction (MPATI) broadcasting instructional programs to school systems in Indiana and five surrounding states from an airfield near Purdue University in Lafayette. MPATI transmitted educational television programs “...to nearly 2,000 public schools and universities reaching almost 400,000 students in 6500 classrooms in Indiana and five surrounding states" (Jeffries, n.d., p. 2). Regardless of its popularity, instructional television was not widely embraced due to the teachers' resistance to television in the classroom, the cost of TV systems, and "... the inability of television alone to meet the various conditions for student learning" (Jeffries, n.d., p. 2).

Computer technology represented the third phase of the distance education development supporting learning. Initially, microwave technology developed microwave networks to take advantage of the Instructional Television Fixed Service (ITFS) authorized by the Federal Communications Commission. In spite of being a closed circuit concept, ITFS technology reached distant students as a branch of the extended classrooms (Jeffries, n.d.). The new 80s space-age brought technology which included computers and space satellites, thereby allowing universities to offer adult education programs and refresher courses to students situated thousands of miles from the actual campuses.

The advancement in the areas of technology and education stimulated the creation of a virtual classroom during the computer technology phase of learning. The Programmed Logic for Automatic Teaching Operations (PLATO) project of the 70s permitted numerous sites to be in contact via dial-up and dedicated connections, thereby creating the first electronic network form of instruction (Moore, 2003; Online Learning History, 2007). The 1980s brought forth the NSFNet which is the "...network of five supercomputer centers connected to universities and research organizations" (Moore, 2003, p. 21). This network created the opportunity for Pennsylvania State University to offer distance education courses in its Adult Education Program in Mexico, Finland, and Estonia.

Several major universities stepped forward to provide Web-based distance instruction in the 1990s, often creating a separate administrative unit allocated specifically for online needs. Some of the providers of online degree programs, who were credited for early involvement, included the New York Institute of Technology, New School for Social Research in New York, and the International School for Social Research in New York. In the late 90s, Moore (2003) reported that $84.1 \%$ of public universities and $83.3 \%$ of 4-year public colleges offered Web-based courses.

An interesting study by Schutte performed an experiment which consisted of splitting a class into separate sections. One section replicated the traditional delivery relying on lectures and written assignments, while the other section received online lectures, email and electronic assignments. The online students quickly adjusted to the environment, subsequently spending about 50 percent more time working together than the traditional recipients. 
Possibly, the team focus provided an explanation for the higher test scores, or simply the additional time dedicated to actual learning could explain the difference (Schutte, 1997).

Parker and Gemino (2001) found that students performed equally as well in Asynchronous Learning Networks (ANL) and place based students in overall scores. While examining the two types of learning, researchers discovered a difference between conceptual and technique based material. The cooperative students were enrolled in the course to limit excessive time commuting between locations. Two sections were offered, allowing one place based and one online course, integrating two primary objectives. The conceptual element focused on the role of a systems analyst, while the technical element focused on diagrams and language as it related to a systems analyst.

It was determined that the ALN students scored higher in the conceptual component than place based students. However, the technical component came in lower when compared to place based students. Increased discussion, resulting from minimal time constraints, was thought to explain the higher conceptual scores for the online classes. Consequently, similar outcomes were discovered for both traditional place-based classes and online classes when evaluating assessments (Parker \& Gemino, 2001). Similarly, another study (Johnson, Aragon, Shaik \& Palma-Rivas, 2000) evaluating online and place-based instruction revealed comparable outcomes. This study relied on courses taught by the same professor utilizing the identical curriculum. The criteria used for comparison data included a course project and a self-assessment instrument. The online and face-to-face learners did not reveal a significant difference in the quality of work. The student perceptions of instructors, course quality, course interaction, and learning outcomes provided the basis for the ratings. The mean rating for the online class was 3.40 out of 4 , while the mean rating for the face-to-face learners was 3.47 out of 4 . While the course grades were evenly distributed for the online and face-to-face learners, the results supported "no significant difference".

A different study tracked college level math students for a period of two years, evaluating pen and paper test scores to online scores and found that, "Students do seem to perform better in the online section...." (Engelbrecht \& Harding, 2004, p. 221). Jennings (2003) studied online students who reported positive perceptions regarding flexibility, self-pacing, lower travel costs and their application of higher level communication skills which were honed through the use of discussions. These same students reported more confidence resulting from their ability to preview the discussion board, subsequently increasing their time to brainstorm the issue prior to a dedicated response. The "online students scored significantly higher in content examinations and experienced greater levels of instructor-student interaction than did students in the traditional on-campus course" (Jennings, 2003 , p. 184). Jennings (2003) further reported that the grade point averages of the online students were 2.68 , while the traditional students revealed a 2.65 .

\section{RESEARCH METHODOLOGY}

This research project utilized the causal-comparative research methodology. The authors compiled the final grades from four Embry-Riddle courses during the 2005 and 2006 calendar years. The courses selected for this study were MGMT 331, Marketing; MGMT 210, Financial Accounting; ASCI 254, Aviation Legislation; and Math 111, College Mathematics for Aviation. In addition to a traditionally large enrollment for these courses, these courses were selected because they covered a spectrum of courses offered by the university both online and in the lecture delivery mode. Data were extracted from student records and a t-test for independent samples was utilized to determine if there was a significant difference in final grades between online and lecture classes. The researchers recognize that combining the final grades for different courses would not be appropriate since differences may exist, so courses were considered separately in this study. The study evaluated whether there could be a difference in grades between online courses from 2005 to 2006 when the online classes were converted from a proctored to a nonproctored model. Information was accumulated to determine if there was a significant difference between the grade point average of courses taken both before and after the initiation of on-line testing. It is feasible that while there is a significant difference in examination grades, there may not be a difference in overall course grades since the course monitors have adjusted other requirements associated with the course. 


\section{RESULTS}

The data for the non-proctored online examination were from classes conducted during the months of January through June of 2006. While some Embry-Riddle courses are available 11 times a year, starting every month except December, others are offered less frequently, reliant upon the demand.

Table 1

Management 331 - Online Verses Lecture Final Grades

t-Test: Two-Sample Assuming Unequal Variances

MGMT 331 Online vs Lecture (2005 and 2006)

\begin{tabular}{lll}
\hline & $D L$ & $L$ \\
\hline Mean & 3.224299065 & 3.561111111 \\
Variance & 1.307885924 & 0.551322457 \\
Observations & 428 & 900 \\
Hypothesized Mean Difference & 0 & \\
df & 604 & \\
$\mathrm{t}$ Stat & -5.56096215 & \\
$\mathrm{P}(\mathrm{T}<=\mathrm{t})$ one-tail & $2.01618 \mathrm{E}-08$ & \\
$\mathrm{t}$ Critical one-tail & 1.647380321 & \\
$\mathrm{P}(\mathrm{T}<=$ t) two-tail & $4.03237 \mathrm{E}-08$ & \\
$\mathrm{t}$ Critical two-tail & 1.963899244 \\
\hline
\end{tabular}

Table 2

Management 210 - Online Verses Lecture Final Grades

t-Test: Two-Sample Assuming Unequal Variances MGMT 210 Online vs Lecture (2005 and 2006)

\begin{tabular}{lll}
\hline & & \\
\hline Mean & $D L$ & 2.283030303 \\
Variance & 2.545454545 & 0.818929887 \\
Observations & 1.511521202 & 3300 \\
Hypothesized Mean Difference & 1804 & \\
df & 0 & \\
t Stat & 2891 & \\
P $(T<=t)$ one-tail & -22.3812942 & \\
t Critical one-tail & $9.3389 \mathrm{E}-103$ & \\
P $(\mathrm{T}<=t)$ two-tail & 1.645380871 & \\
t Critical two-tail & $1.8678 \mathrm{E}-102$ & \\
\hline
\end{tabular}

Table 3

Aeronautical Science 254 - Online Verses Lecture Final Grades

t-Test: Two-Sample Assuming Unequal Variances ASCI 254 Online vs Lecture (2005 and 2006)

\begin{tabular}{lll}
\hline & $D L$ & $L$ \\
\hline Mean & 2.620256776 & 3.510313901 \\
Variance & 1.552957126 & 0.575327204 \\
Observations & 3505 & 3345 \\
Hypothesized Mean Difference & 0 & \\
df & 5832 & \\
t Stat & -35.88866339 \\
P(T<=t) one-tail & $2.4089 \mathrm{E}-255$ \\
t Critical one-tail & 1.645114946 \\
P(T<=t) two-tail & $4.8179 \mathrm{E}-255$ \\
t Critical two-tail & 1.960370781 \\
\hline
\end{tabular}


Table 4

Mathematics 111 - Online Verses Lecture Final Grades

t-Test: Two-Sample Assuming Unequal Variances

Math 111 Online vs Lecture (2005 and 2006)

\begin{tabular}{lll}
\hline & $D L$ & $L$ \\
\hline Mean & 2.349809886 & 3.178977273 \\
Variance & 1.655791948 & 1.007034632 \\
Observations & 263 & 1408 \\
Hypothesized Mean Difference & 0 \\
df & 324 \\
t Stat & -9.902660913 \\
P $(\mathrm{T}<=$ t) one-tail & $1.13545 \mathrm{E}-20$ \\
$\mathrm{t}$ Critical one-tail & 1.649570176 \\
$\mathrm{P}(\mathrm{T}<=\mathrm{t})$ two-tail & $2.27089 \mathrm{E}-20$ \\
$\mathrm{t}$ Critical two-tail & 1.967312704 \\
\hline
\end{tabular}

\section{DISCUSSION}

Results from the t-tests revealed a significance difference in both the midterm and final grades between the proctored and online non-proctored examinations. While the scores were significant, they did not appear to be excessive.

\section{CONCLUSIONS}

The t-test results for the four courses revealed a significant difference between the online and lecture course final grades. The hypothesis for the study, that there would be a significant difference between the online and lecture final course grades was supported and the null hypothesis rejected. However, the authors had hypothesized that the final grades for the lecture classes would be significantly higher, and this was not the case. In all four classes the grades for the online classes was significantly lower as compared to the lecture classes. The difference between the means for online MGMT 311 was 3.22 as compared to 3.56 for the lecture classes; for MGMT 210 it was 2.54 as compared to 3.28; for ASCI 254 it was 2.60 as compared to 3.51; and for MATH 111 it was 2.34 compared to 3.17. A follow-on study is recommended to analyze the final grades for the courses to determine if there is significance between proctored and non proctored online testing.

\section{AUTHOR INFORMATION}

Dr. Marian Schultz completed her undergraduate degree from the University of Detroit Mercy, a Master's degree from Pepperdine University, and a Doctorate from the University of Southern California. She taught for The University of Hawaii, The University of Texas at San Antonio Chaminade University, Hawaii Pacific College and St. Mary's University School of Business and Administration, Embry Riddle Aeronautical University and is currently a tenured full professor for The University of West Florida, Department of Management/MIS. Her consultant work includes Pace Foods of San Antonio, The Winning Edge, $149^{\text {th }}$ Tactical Fighter Group of the Texas Air National Guard, First City Bank, and Health America and Eglin AFB. Her research has been presented regionally, nationally and internationally.

Dr. Jim Schultz holds a Bachelor's degree from Michigan State University, a Master's degree from The University of Oklahoma, a Master's Degree from Embry-Riddle Aeronautical, and a Doctorate from the University of Southern California. He retired from the U.S. Air Force as a Lt. Colonel in 1992. Dr. Schultz has published at the regional, national and international levels. He has served as a consultant for Pace Foods, Medical Supplies Corporation of Hawaii, First City Bank, World Airlines Pilots Association, and the 149th Tactical Fighter Group, and the $46^{\text {th }}$ Air 
Base Wing, Eglin AFB, Florida. He holds FAA pilot ratings and is currently a tenured Professor of Leadership, Management \& Technology, and the Chair of the Department of Arts \& Letters.

Dr. Gene Round retired from the US Air Force in 1992 after 26 years of service in a variety of career areas. He completed undergraduate degree is in mathematics education from the University of Wyoming, Master's degree in mathematics from the Colorado State University, and earned his Doctorate from Ohio State. His experience includes Air Force service as a mathematician, head of two manpower and management engineering organizations, head of an operations research organization at a defense agency, and in financial management, as well as being a pilot. He is a member of the American Statistical Association, the National Council of Teachers of Mathematics, and the American Mathematical Association of Two Year Colleges. He has taught for New Mexico State University, El Paso Community College, and Mexico State University. He is currently a tenured Associate Professor for Embry Riddle Aeronautical University.

\section{REFERENCES}

1. Gooch, J. (1998). They Blazed the Trail for Distance Education. Distance Education Clearinghouse. Retrieved July 17, 2007, from http://www.uwex.edu/disted/gooch.cfm

2. Grenier-Winther, J. (1999). Real Issues in the Virtual Classroom. The French Review, 73, 252-264. Retrieved July 14, 2007, from Jstor database.

3. Jeffries, M. (n.d). Research in Distance Education. MA Distributed Learning. Retrieved July 17, 2007, from http://www.digitalschool.net/edu/DL history mJeffries.html

4. Kulik, J. A., Kulik, C. C., \& Cohen, P. A. (1990). Effectiveness of Computer-Based College Teaching: A Meta-Analysis of Findings. Review of Educational Research, 50, 525-544. Retrieved July 15, 2007, from Jstor database.

5. Larreamendy-Joerns, J., \& Leinhardt, G. (2006) ERIC Educational Research Information Center. Review of Educational Research, v76 n4 p567-605. Retrieved July 17, 2007, from http://eric.ed.gov/ERICWebPortal/Home.portal? nfpb=true\&ERICExtSearch_SearchValue 0=going+dista nce+with+online+education\&searchtype=keyword\&ERICExtSearch_SearchType $0=k w \&$ pageLabel=Rec ordDetails\&objectId $=0900019 \mathrm{~b} 801631 \mathrm{f0} \& \mathrm{accno}=\mathrm{EJ} 759796 \&$ nfls $=$ false

6. Moore, M. (2003) Educational Research Information Center. Publications, Center on Education and Training for Employment. Columbus, OH. Retrieved on July 17, 2007, from http://eric.ed.gov/ERICWebPortal/Home.portal? nfpb=true\&ERICExtSearch_SearchValue 0=from+chaut auqua\&searchtype=keyword\&ERICExtSearch_SearchType_0=kw\&_pageLabel=RecordDetails\&objectId= 0900019b800ecd78\&accno=ED482357\&_nfls=false

7. Online Learning History, February 28, 2007, Retrieved July 21, 2007 From http://docs.moodle.org/en/Online_Learning_History

8. Online Learning Survey, Sloan Consortium, 2007, Retrieved July 21, 2007 From http://www.sloanc.org/resources/index.asp

9. Schultz, M., Schultz, J., \& Gallogly, J. (2007). The Management of Testing in the Distance Learning Environments, Journal of College Teaching \& Learning, 4, 19-26.

10. Schutte, J. G. (1997). Virtual Teaching and Higher Education; The New Intellectual Superhighway or just another Traffic Jam? Retrieved July 20, 2007 From http://www.csun.edu/sociology/virexp.htm

11. Tatkovic, N., \& Ruzic, M. (2006) Educational Research Information Center. Retrieved July 17, 2007, from http://eric.ed.gov/ERICWebPortal/Home.portal? nfpb=true\&ERICExtSearch_SearchValue $0=$ open+distan ce+learning\%3A+pedagogical+terms+of+reference+and+dilemmas\&searchtype=keyword\&ERICExtSearc $\underline{\mathrm{h} \_ \text {SearchType } 0=k w \& \text { pageLabel=RecordDetails\&objectId }=0900019 \mathrm{~b} 8015 \mathrm{~d} 273 \& \text { accno=ED } 494214 \& \_\mathrm{nf}}$ $\underline{\text { ls=false }}$

12. Tesone, D. (2003). Distance Learning Programs for Non-Traditional and Traditional Students in the Business Disciplines (4th ed., Vol. 6) [Distance Learning Programs for Non-Traditional and Traditional Students in the Business Disciplines]. Retrieved July 16, 2007, from Online Journal of Distance Learning Administration Web site: http://www.westga.edu/ distance/ojdla/winter64/tesone64.html

13. Wellman, G. (2005). Comparing Learning Styles in Online Teaching: Impact of Proctored v. Unproctored Testing, Journal of Interactive Online Learning, 4, 20-39. 